\title{
Effect of a new beta-adrenergic blocking agent, ICI 66082, on exercise haemodynamics and airway resistance in angina pectoris
}

\author{
Hans Åström and Hans Vallin \\ From the Department of Clinical Physiology, Thoracic Clinics, Karolinska Sjukhuset, Stockholm, Sweden
}

\begin{abstract}
$A$ new cardioselective beta-adrenergic blocking agent, ICI 66082, was studied in Io patients with severe effort-limiting angina pectoris, of whom all but one later went to bypass operation. The effect on maximal working capacity and airways resistance was compared before and after a single intravenous dose of $5 \mathrm{mg} I C I$ 66082 and propranolol. The haemodynamic effects of ICI 66082 were also studied during cardiac catheterization in the same patients during supine exercise provoking chest pain.

Propranolol and ICI 66082 were equipotential in their blocking effect on exercise heart rate. In contrast to propranolol, ICI 66082 did not block the beta-receptors of the lung. Maximal working capacity was higher after ICI 66082 than after propranolol $(+9 \%)$ and compared to the control period $(+19 \%)$. This could be explained by a decrease found, after ICI 66082 administration, in both cardiac ouput (stroke volume unchanged) and aortic pressure during exercise with no change in the peripheral vascular resistance.
\end{abstract}

The beneficial effect of beta-adrenergic blockade in the treatment of angina pectoris is well documented (Epstein and Braunwald, 1966). Since propranolol was introduced, several other beta-adrenergic blocking agents with slightly different pharmacological properties have been introduced, in an effort to avoid the side effects of generalized beta-blockade, particularly with respect to the beta-receptors in the lung. Propranolol has been shown to have a significant therapeutic effect in hypertension, in spite of its beta-blocking effect on peripheral vessels (Prichard and Gillam, 1964). Theoretically this peripheral effect should hinder the achievement of an immediate pressure lowering effect.

Preliminary animal studies have shown that ICI 66082,4 -(2-hydroxy-3-isopropylaminopropoxy)phenyl acetamide, blocks the beta-receptors specifically in the heart (Barrett et al., 1973). It does not block peripheral vascular receptors and possesses no intrinsic sympathicomimetic or membrane stabilizing property. Furthermore it does not cross the blood-brain barrier. These qualities should be of advantage in the treatment of angina pectoris and hypertension. The findings in the present study suggest that the cardioselective ICI 66082 has such advantages as compared to propranolol in the treatment of angina pectoris.

Received 22 April I974.

\section{Subjects, methods, and procedure}

Ten male subjects, aged 36 to 62 years, were investigated. All had effort induced angina pectoris with significant coronary artery stenosis verified with selective coronary angiography. Some clinical and anthropometric data are listed in Table I. All but one later went to bypass operation because of intractable angina pectoris. All medication was withdrawn at least 2 days before the present investigations. None was on digitalis or diuretics and none had hypertension or diabetes.

Work tests were performed on a bicycle ergometer with increments of Io Ws every minute from an initial work load of Io Ws. All subjects exercised to their tolerance limits for chest pain and this was called $\mathrm{W}_{\max }$. $\mathrm{A}$ six-lead chest electrocardiogram was recorded during the whole exercise procedure. The heart rate was calculated from the electrocardiogram during the last io seconds at every load. This work test was repeated on two separate days after administration of $5 \mathrm{mg}$ propranolol and ICI 66082 i.v. in a random order. Ten minutes after this administration and immediately before the exercise test the airway resistance was measured with a body plethysmograph (Brunes and Holmgren, 1966). All exercise tests were performed in the morning at least I hour after a light breakfast on the same electrically braked bicycle ergometer. The reproducibility of a single $W_{\max }$ test calculated from duplicate determinations performed within 4 days in another group of patients with similar severity of coronary artery disease has proven to be 6.6 per cent in our laboratory. Thus 
TABLE I Anthropometric, clinical, and functional data in 10 patients with angina pectoris

\begin{tabular}{|c|c|c|c|c|c|c|c|c|}
\hline Case No. & $\begin{array}{l}\text { Age } \\
(y r)\end{array}$ & $\begin{array}{l}\text { Weight } \\
(\mathrm{kg})\end{array}$ & $\begin{array}{l}B S A \\
\left(m^{2}\right)\end{array}$ & $\begin{array}{l}\text { Time from } \\
\text { infarction to } \\
\text { investigation }\end{array}$ & $\begin{array}{l}\text { Angina } \\
\text { pectoris } \\
\text { duration }\end{array}$ & $\begin{array}{l}\text { Heart } \\
\text { volume } \\
\left(\mathrm{ml} / \mathrm{m}^{2}\right)\end{array}$ & $\begin{array}{l}W_{\max } \\
\text { sitting } \\
\text { (Watts) }\end{array}$ & $\begin{array}{l}\text { Work supine at } \\
\text { catheterization } \\
\text { (Watts) }\end{array}$ \\
\hline I & 56 & 77 & I 94 & - & $7 \mathrm{yr}$ & 400 & - & 20 \\
\hline 2 & 45 & 63 & $I \cdot 74$ & $7 \mathrm{mth}$ & I yr & 420 & 80 & 20 \\
\hline 3 & 43 & 83 & $2 \cdot 04$ & $2 \mathrm{yr}$ & 2 yr & 420 & 70 & IO \\
\hline 4 & 36 & 65 & $I \cdot 77$ & - & $3 \mathrm{mth}$ & 420 & 90 & IO \\
\hline 5 & 56 & 75 & $I \cdot 8 I$ & I yr & IO yr & 460 & 100 & 20 \\
\hline 6 & 62 & 85 & 2.03 & - & $3 \mathbf{y r}$ & 630 & - & 20 \\
\hline 7 & 45 & 80 & $I \cdot 95$ & - & $2 \mathrm{yr}$ & 370 & 100 & 20 \\
\hline 8 & 59 & 91 & $2 \cdot 14$ & - & I yr & 470 & 90 & IO \\
\hline $9:$ & 49 & 77 & $I \cdot 86$ & - & I yr & 370 & 150 & 20 \\
\hline IO & 48 & 82 & I 99 & I yr & $4 \mathrm{yr}$ & 330 & 70 & IO \\
\hline
\end{tabular}

differences in $W_{\max }$ of more than ro Ws (i.e. one step) is expected to be significant at work rates around $100 \mathrm{Ws}$.

The last step of the investigation was a right heart catheterization, performed with a double-lumen catheter introduced percutaneously in a right cubital vein. The left heart catheterization was performed via a 'teflon' catheter introduced percutaneously in the right brachial artery. The cardiac output was determined with the direct Fick method. The rate-pressure index was calculated as the product of systolic pressure in aorta and heart rate (Robinson, 1967). $\mathrm{pH}$, carbon dioxide, and base excess were determined with the microequilibration technique. The techniques and procedures were the same as described previously in more detail from our laboratory (Åström, 1968).

Heart catheterization was performed in the morning after oral premedication with $0.8 \mathrm{~g}$ meprobamate. The subjects were studied at rest and during work in supine position. The work load had been determined previously to induce moderate chest pain but still work could be continued for 6 to 8 minutes. After a resting period of 30 to 40 minutes, $5 \mathrm{mg}$ ICI 66082 was given in the pulmonary artery and ro minutes later the procedure was repeated.

The nature and purpose of the investigation were explained to the patients and their consent obtained.

\section{Results}

\section{Working capacity $\left(\mathbf{W}_{\max }\right)$}

Eight patients performed a maximal exercise test before and after both ICI 66082 and propranolol. Fig. I shows the close linear correlation between work load in I-minute steps and heart rate. The $\mathrm{W}_{\max }$ in the control period was on an average $93 \cdot 8 \pm 9 \cdot 1$ (SEM) Ws and increased after administration of ICI 66082 to III.3 $\pm 7.7 \mathrm{Ws}(P<0.05)$ and after propranolol to $102.5 \pm 8.8 \mathrm{Ws}$ (n.s.). The difference between the two drugs in the effect on $\mathrm{W}_{\max }$ was significant, while the maximal heart rate

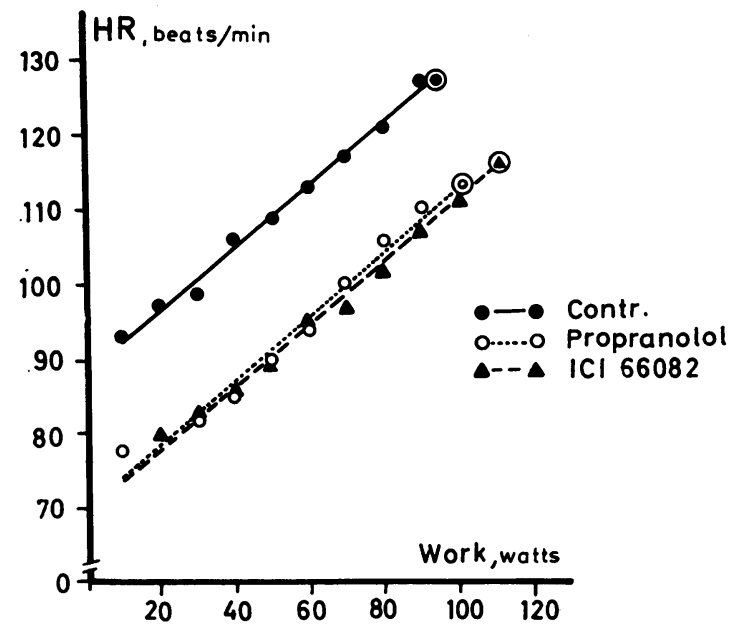

FIG. I Relation between mean values for heart rate $(H R)$ and work load at I-minute step exercise before and after $5 \mathrm{mg}$ of ICI 66082 and propranolol. Symbols with circle represent mean maximal point. Individual control values in Table $I$.

was equal (Fig. 2). After both drugs the subjects stopped the work because of chest pain but at a lower heart rate (Fig. 2).

\section{Airway resistance (Fig. 3)}

Airway resistance was within the normal range in most patients. After ICI 66082 the resistance decreased by 7 per cent $(P<0.05)$ and the airway conductance per litre thoracic gas volume increased by 15 per cent $(\mathbf{P}<0.01)$. It is noteworthy that the patients with signs of slight airway obstruction (i.e. control airway resistance above $3.0 \mathrm{~cm} \mathrm{H}_{2} \mathrm{O} / 1$. per sec. or specific airway conductance below $0.12 \mathrm{l} . / \mathrm{sec}$ per $\mathrm{cm} \mathrm{H}_{2} \mathrm{O}$ ) all had an increase in airway conductance 
Propranolol
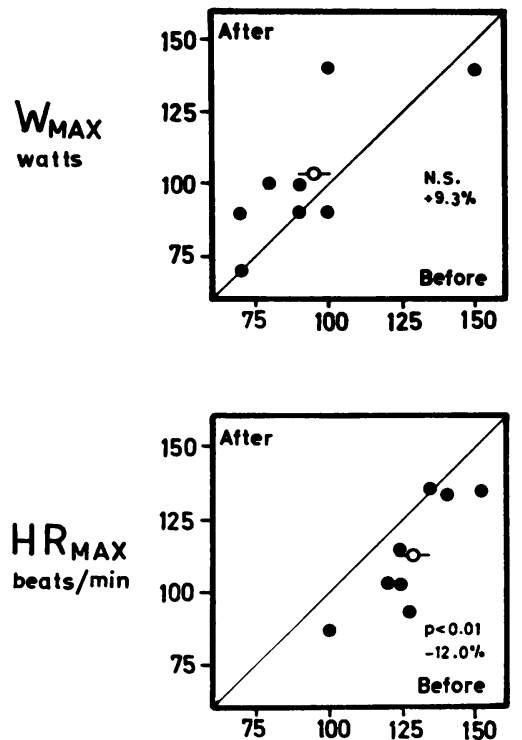

ICI 66082
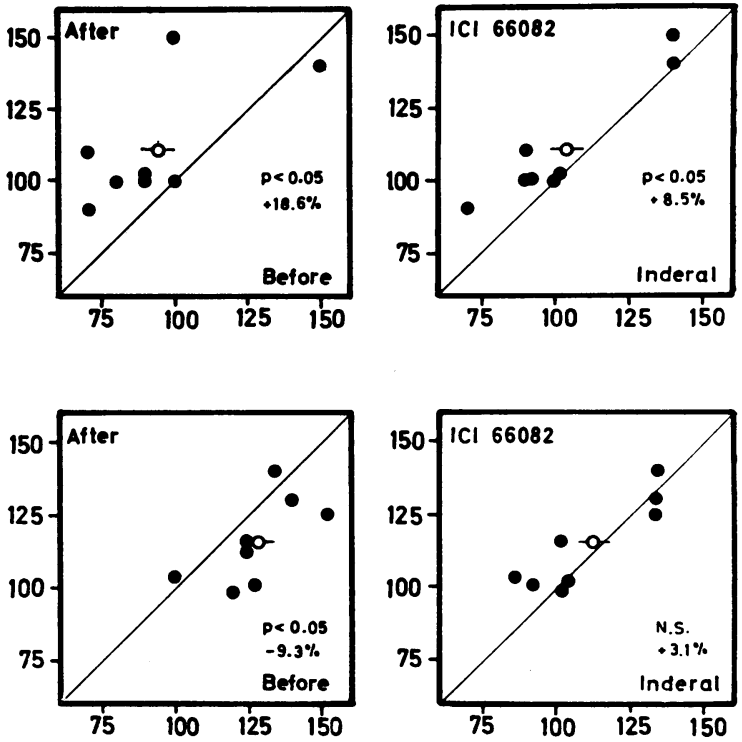

FIG. 2 Maximal power $\left(W_{\max }\right)$ and maximal heart rate $\left(H R_{\max }\right)$ performed before and after ICI 66082 and propranolol. Open circles represent mean value.

$\mathbf{R}_{\mathbf{a}}$.

$\mathrm{CmH}_{2} \mathrm{O} \cdot 1-1 \cdot \sec -1$

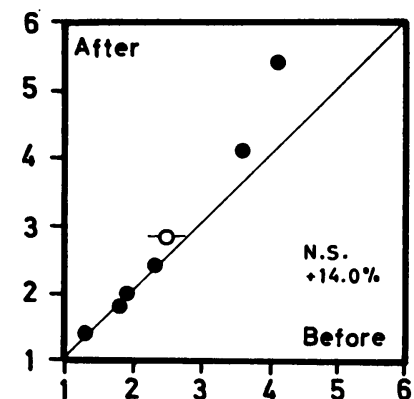

CA/TGV , $\mathrm{sec}^{-1} \cdot \mathrm{CmH}_{2} \mathrm{O}^{-1}$

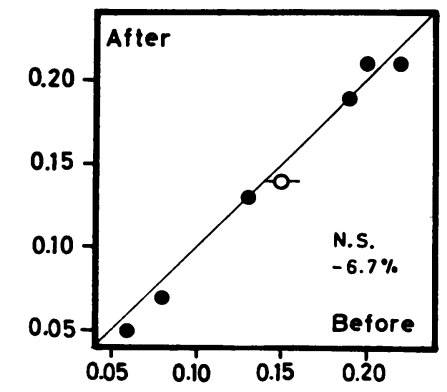

ICI 66082

$n=10$
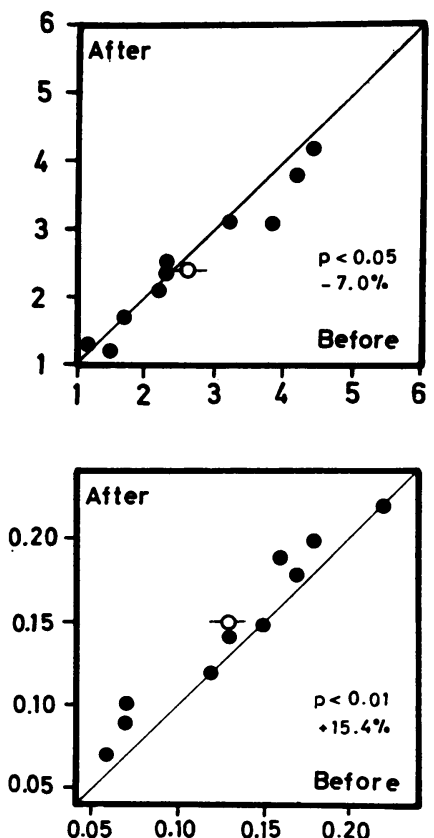

FIG. 3 Airway resistance $\left(R_{\mathrm{a}}\right)$ and airway conductance per litre thoracic gas volume $\left({ }^{\mathrm{C}} A / T G V\right)$ before and after ICI 66082 and propranolol. 
TABLE 2 Mean values for haemodynamic variables before and after $5 \mathrm{mg}$ ICI 66082 i.v. for individual differences and significance of differences

\begin{tabular}{|c|c|c|c|c|c|c|c|c|c|}
\hline & \multirow{2}{*}{$\begin{array}{l}\mathrm{O}_{2} \\
\text { uptake } \\
\text { (ml/min) }\end{array}$} & \multirow{2}{*}{$\begin{array}{l}\text { Heart rate } \\
\text { (beats/min) }\end{array}$} & \multirow{2}{*}{$\begin{array}{l}\text { Arterio- } \\
\text { venous } \\
\text { diff } \\
(\mathrm{ml} / \mathrm{l} .)\end{array}$} & \multirow{2}{*}{$\begin{array}{l}\begin{array}{l}\text { Cardiac } \\
\text { ouput }\end{array} \\
\text { (l./min) }\end{array}$} & \multirow{2}{*}{$\begin{array}{l}\text { Stroke } \\
\text { volume } \\
(m l)\end{array}$} & \multicolumn{3}{|c|}{ Pressure $(m m H g)$ (mean) } & \multirow{2}{*}{$\begin{array}{l}\text { Rate-pressure } \\
\text { index } \times 10^{-2}\end{array}$} \\
\hline & & & & & & Aorta & $P C V$ & $P A$ & \\
\hline \multicolumn{10}{|l|}{ Rest } \\
\hline Before & 257 & 83 & 46 & $5 \cdot 7$ & 70 & 97 & 10 & 16 & $97 \cdot 6$ \\
\hline After & 243 & 69 & 53 & $4 \cdot 6$ & 68 & 95 & II & 17 & $79 \cdot 9$ \\
\hline Difference & 14 & 14 & -7 & $\mathbf{I} \cdot \mathbf{I}$ & 2 & 2 & $-I$ & $-I$ & $17 \cdot 7$ \\
\hline $\mathbf{P}$ & $<0.02$ & $<0.001$ & $<0.01$ & $<0.001$ & NS & NS & NS & NS & $<0.001$ \\
\hline \multicolumn{10}{|l|}{ Exercise } \\
\hline Before & 601 & IOI & 77 & $8 \cdot 0$ & 79 & 115 & 22 & 32 & 146.9 \\
\hline After & 592 & 85 & 91 & $6 \cdot 7$ & 79 & 103 & 19 & 28 & 110.5 \\
\hline Difference & 9 & 16 & -14 & $1 \cdot 3$ & 0 & 12 & 3 & 4 & $36 \cdot 4$ \\
\hline $\mathbf{P}$ & NS & $<0.001$ & $<0.01$ & $<0.001$ & NS & $<0.001$ & NS & NS & $<0.001$ \\
\hline
\end{tabular}

$\mathbf{P}=$ probability, paired t-test.
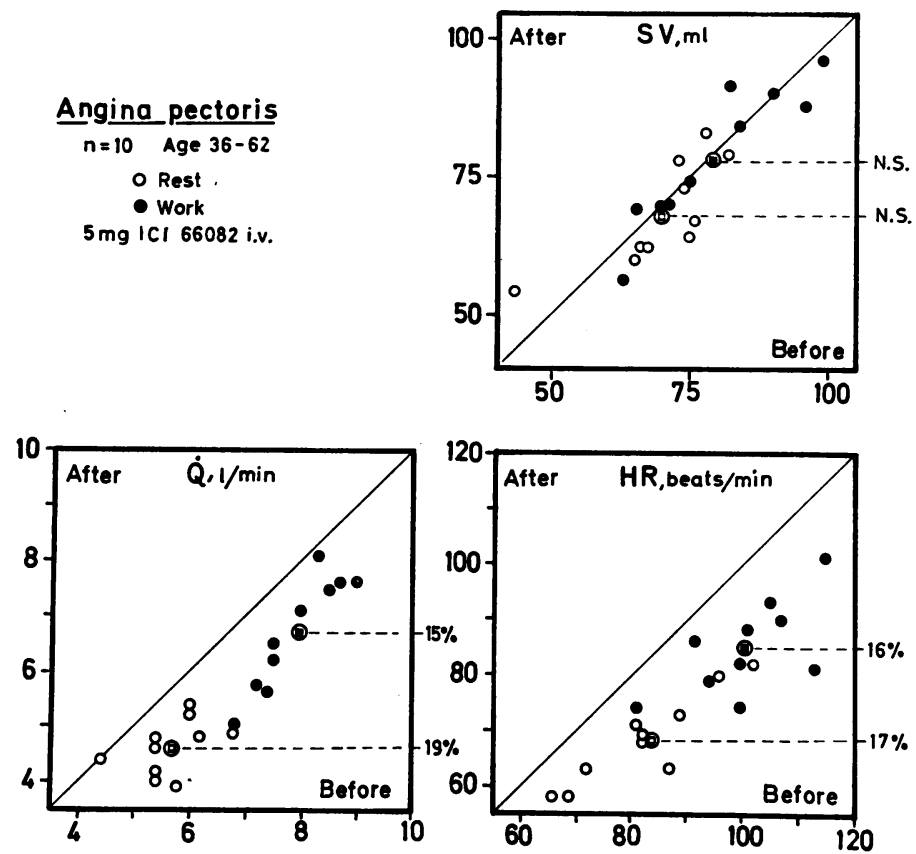

FIG. 4 Stroke volume $(S V)$, cardiac ouput $(\dot{Q})$, and heart rate $(H R)$ before and after ICI 66082 in ro patients with angina pectoris at rest $(0)$ and during exercise (๑). Square with circle represents mean value.

after ICI 66082 but a further decrease after the same amount of propranolol was administered.

\section{Haemodynamics (Table 2)}

Oxygen consumption was slightly reduced after ICI 66082 at rest $(P<0.05)$ but was unchanged during exercise. All subjects could work without chest pain after ICI 66082 at that work load which caused pain before treatment. This fact did not affect the total oxygen uptake and thus not the mechanical efficiency. Cardiac output at rest was diminished by 19 per cent and during work by 15 per cent. This change was caused by a decrease in 

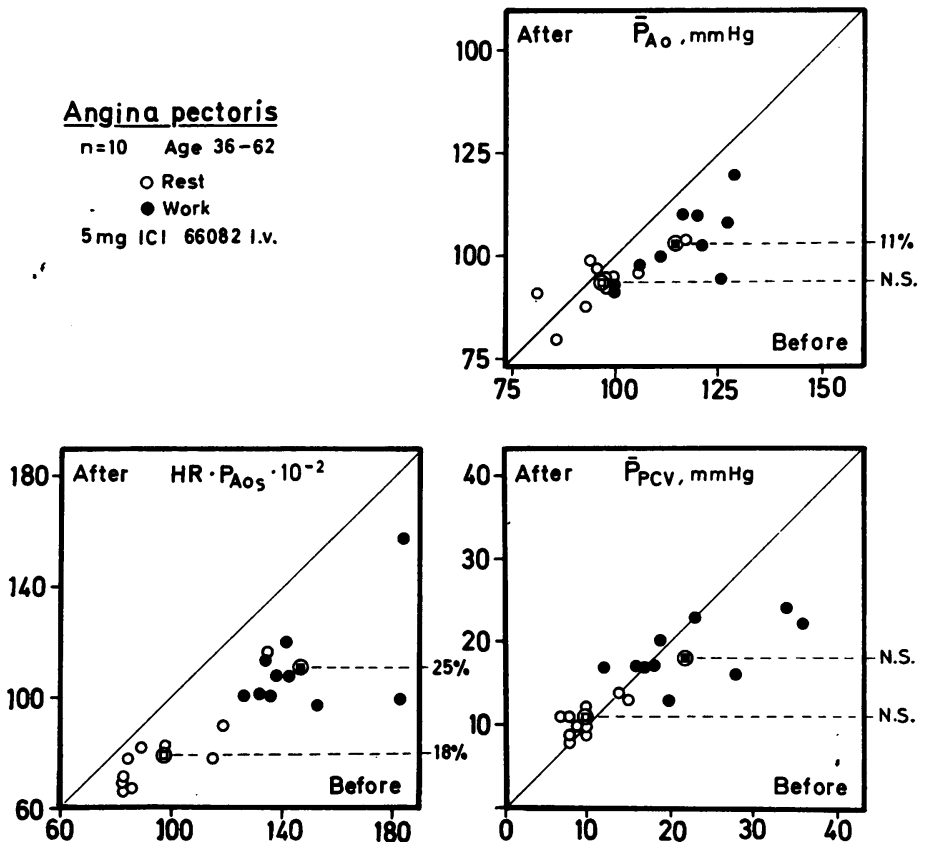

FIG. 5 Aortic mean pressure $\left(\bar{P}_{\mathrm{AO}}\right)$, rate-pressure index, and pulmonary artery wedge pressure $\left(\bar{P}_{\mathrm{PCV}}\right)$ before and after ICI 66082. Symbols as in Fig. 4.

heart rate alone as stroke volume was unchanged both at rest and during work (Fig. 4). At rest the pressures in aorta, pulmonary artery wedge, pulmonary artery, and right atrium were all within normal range, and no significant change was found after ICI 66082. During exercise before beta-blockade provoking angina pectoris in all subjects the wedge pressure increased abnormally. The magnitude of this increase was not significantly changed after blockade. However, in 3 patients with wedge pressure above $25 \mathrm{mmHg}$ this pressure decreased after blockade by an average of $12 \mathrm{mmHg}$ (Fig. 5). The pulmonary artery mean pressure was also unchanged after blockade. The aortic pressure increased during exercise but the increment after ICI 66082 was significantly less $(12.6 \mathrm{mmHg}, P<0.001$ ) than during control period. The systemic vascular resistance during work was unchanged by drug administration. The rate-pressure index decreased by 18 per cent at rest and 25 per cent at work $(\mathrm{P}<0.00 \mathrm{r})$. There was no difference found in $\mathrm{pH}$, base excess, or carbon dioxide either at rest or during work.

\section{Discussion}

All patients in this study had effort induced angina pectoris and all but one later went to bypass opera- tion. A standardized multistage exercise test was used to evaluate the tolerance limit for angina pectoris. From this test it is also seen that ICI 66082 and propranolol are equipotential concerning the blocking effect on heart rate increase during exercise (Fig. 3).

In the present study the maximal work rate was higher after ICI 66082 than after propranolol. The relative bradycardia was the same for both agents. The difference in $\mathbb{W}_{\max }$ might be explained by their different action on the arterial pressure, as this, together with heart rate, is one of the major determinants for the myocardial oxygen consumption (Sarnoff et al., 1958). The rate-pressure index decreased by 25 per cent after ICI 66082. From an earlier study on the haemodynamic effects of propranolol (Åström, 1968), a recalculation of the rate-pressure index showed a decrease of 15 per cent (Fig. 6). It was recently shown that the ratepressure product was a better index of the myocardial oxygen consumption than the tension-time index despite a change in contractility induced by propranolol (Jorgensen et al., 1973).

The aortic pressure was unchanged at rest, with an increase in the peripheral vascular resistance after blockade with ICI $\mathbf{6 6 0 8 2}$. During exercise, however, the resistance was unchanged with a 
Angina pectoris

\begin{tabular}{ccc}
\hline Rest Work & $n$ \\
0 & $5 \mathrm{mg}$ Propranolol i.v. & 8 \\
$\Delta$ & 5 & 5
\end{tabular}
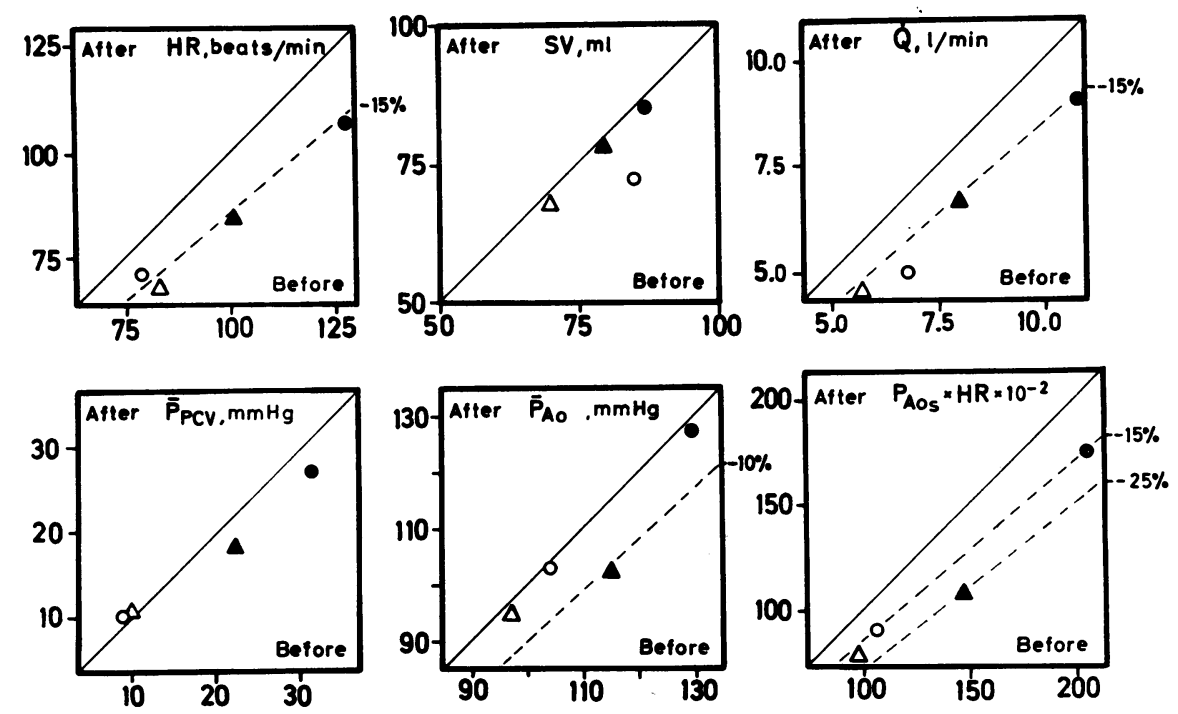

FIG. 6 Comparison between mean values for heart rate $(H R)$, stroke volume $(S V)$, cardiac output $(\dot{Q})$, pulmonary artery wedge pressure $\left(\bar{P}_{\mathrm{PCV}}\right)$, aortic mean pressure $\left(\bar{P}_{\mathrm{Ao}}\right)$, and rate-pressure index before and after ICI 66082 and propranolol. The effect of proprainolol has been plotted from the study by Aström (1968).

lower aortic pressure related to the decrease in cardiac output. Propranolol increases the peripheral vascular resistance both at rest and during exercise when given acutely as it blocks the beta-adrenergic vasodilator receptors (Hamer and Sowton, 1965). The cardioselective beta-blocking agent, practolol, has been reported not to change systemic arterial pressure nor peripheral resistance during erect exercise in normals (Gibson and Sowton, 1968). In patients with coronary heart disease practolol has been reported to decrease the arterial pressure during exercise, inducing angina pectoris (Rousseau, Brasseur, and Detry, 1973).

The difference in haemodynamic action between the cardioselective practolol and the non-selective propranolol has been thought to be caused by their different action on the peripheral vascular bed. Gibson and Coltart (1972) found that practolol did not produce a fall in cardiac output when the heart rate decreased and suggested that this was because significant peripheral circulatory betasympathetic activity was preserved. This is also in accordance with the present finding for ICI 66082 that stroke volume was not changed at rest in contrast to propranolol, after which it has been shown to decrease (Hamer and Sowton, 1965). During exercise the stroke volume was unchanged after this new beta-blocking agent as also found after propranolol (Åström, I968).

During exercise producing symptoms of myocardial ischaemia, the wedge pressure increased abnormally in all patients. After blockade this pressure dropped slightly as an average. However, a more pronounced fall was noticed after blockade in the subjects with high filling pressure for the left ventricle during the control period. This is similar to what has been shown after propranolol (Åström, 1968) and suggests that the high increase in filling. pressure provoked during angina pectoris is not necessarily a sign of chronic myocardial failure but rather a reversible change in the myocardial contractility and wall compliance secondary to the hypoxia.

ICI 66082 did not increase airway resistance, particularly not in patients with high resistance during the control period. This is in contrast to the non-selective beta-blocking agent propranolol (McNeill, 1964). The actual slight decrease in airway resistance after ICI 66082 might be explained by a reflex beta-stimulation of the lungs elicited by the haemodynamic changes. This implies less risk if the drug be given to asthmatic subjects. 
In conclusion ICI 66082 has proved to be a cardioselective beta-adrenergic blocking agent with apparently no adverse effect on respiratory mechanics. Its haemodynamic action seems similar to that of practolol, with no effect on the peripheral vascular resistance during exercise. ICI 66082 is supposed not to enter the brain and would thus give less side-effects such as troublesome dreams sometimes produced by propranolol and practolol (Wiseman, 1971).

We are grateful to P. E. Hörnkvist, ICI-Pharma, Sweden for supplies of ICI 66082 .

\section{References}

Åström, H. (1968). Haemodynamic effects of beta-adrenergic blockade. British Heart fournal, 30, 44.

Barrett, A. M., Carter, J., Fitzgerald, J. D., Hull, R., and Le Count, D. (1973). A new type of cardioselective adrenoceptive blocking drug. British fournal of Pharmacology, 48 (2), $340 \mathrm{P}$.

Brunes, L., and Holmgren, A. (1966). Total airway resistance and its relationship to body size and lung volumes in healthy young women. Scandinavian fournal of Clinical and Laboratory Investigation, 18, 316.

Epstein, S. E., and Braunwald, E. (1966). Beta-adrenergic receptor blocking drugs. Mechanisms of action and clinical applications. New England fournal of Medicine, 275, I 106.

Gibson, D., and Sowton, E. (1968). Effects of ICI 50172 in man during erect exercise. British Medical fournal, r, 213.
Gibson, D. G., and Coltart, D. J. (1972). Haemodynamic effects of practolol. British Heart fournal, 34, 95.

Hamer, J., and Sowton, E. (1965). Cardiac output after betaadrenergic blockade in ischaemic heart disease. British Heart fournal, $27,892$.

Jorgensen, C. R., Wang, K., Wang, Y., Gobel, F. L., Nelson, R. R., and Taylor, H. (1973). Effect of propranolol on myocardial oxygen consumption and its hemodynamic correlates during upright exercise. Circulation, 48, I 173.

McNeill, R. S. (1964). Effect of beta-adrenergic-blocking agent on asthmatics. Lancet, 2, 1 IOI.

Prichard, B. N. C., and Gillam, P. M. S. (1964). The use of propranolol in the treatment of hypertension. British Medical fournal, 2, 725.

Robinson, B. F. (1967). Relation of heart rate and systolic blood pressure to the onset of pain in angina pectoris. Circulation, 35, 1073.

Rousseau, M. F., Brasseur, L. A., and Detry, J-M. R. (1973). Haemodynamic and electrocardiographic effects of practolol during upright exercise in coronary heart disease. Cardiovascular Research, 7, 306.

Sarnoff, S. J., Braunwald, E., Welch, G. H., Jr., Case, R. B., Stainsby, W. N., and Macruz, R. (1958). Hemodynamic determinants of oxygen consumption of the heart with special reference to the tension-time index. American fournal of Physiology, 192, 148.

Wiseman, R. A. (I97I). Practolol - accumulated data on unwanted effects. Postgraduate Medical fournal, 47, January, Suppl. 68.

Requests for reprints to Dr. Hans Åström, Department of Clinical Physiology, Thoracic Clinics, Karolinska Sjukhuset, S-104 oI Stockholm 60, Sweden. 